Brit. f. vener. Dis. (1971) 47, 348

\title{
Clinical progression of ocular syphilis and neurosyphilis despite treatment with massive doses of penicillin. Failure to demonstrate treponemes in affected tissues
}

\author{
C. N. SOWMINI \\ From the Institute of Venereology, Government General Hospital, and the Department of Venereology, Madras \\ Medical College, Madras-3, India
}

The progression of an infectious disease despite 'adequate therapy' may be an enigma to the clinician in the present antibiotic era. In certain diseases, such as tuberculosis, the resistance of the causative organism to the antibiotics used may explain the progression. There are certain other diseases in which such resistance can only partly explain the failure of treatment. With syphilis it would appear that more than one factor may be involved in the progression of disease.

The worsening of the signs and symptoms of the original lesion or the development of new lesions elsewhere despite 'adequate treatment' can be called 'clinical progression'. It is particularly liable to occur in cases of ocular syphilis and of neurosyphilis, and may appear at any time after treatment, either at the site originally affected or at an entirely different site. Organisms resembling treponemes may or may not be present in the tissues. Serological tests for syphilis may or may not give positive results; hence, diagnosis largely depends on historical, epidemiological, and clinical evidence.

In the management of ocular syphilis and of neurosyphilis, the clinician has to consider the possibility of early or of long-standing syphilis and the possibility of reinfection or of superinfection with the disease; in some cases there may be an association with chronic infections such as tuberculosis, leprosy, and filariasis; or with other disorders such as diabetes mellitus, hypertension, atherosclerosis, and malnutrition.

In a small but significant group of cases the disease progresses. This group is important because it suggests that penicillin has not entirely eliminated the development of late syphilis; bccause its pathogenesis is not clearly understood, this matter requires further study. Accurate diagnosis in such cases is not easy and, in view of our lack of knowledge regarding the exact pathogenesis, specific treatment cannot always be based on sound principles.

Received for publication March 17, 1971

Paper presented at the International Colloquium on Late Treponematoses, Miami, Florida, U.S.A., on January 4 to 8,1971
It seems that the persistence of treponemes may not be necessary for the disease to progress in certain $t$ circumstances. Thus, when the appropriate neuro- ir logical damage has been caused by syphilitic infection, $\omega$ Charcot's disease of the joints may develop because $\infty$ of that irreversible neurological damage. Similarly, 으 if the wall of the aorta has been damaged by the $\overrightarrow{ }$ infection, an aneurysm may develop after treatment, particularly in the presence of hypertension.

\section{Report of seven cases}

Case 1, a 34-year-old man, presented himself at the $\vec{\varphi}$ Institute of Venereology in 1962 with a history of syphifos and the following clinical manifestations:

$i$ Charcot's arthropathy of the right knee and rig ankle of 3 years' duration (Figs 1 and 2)

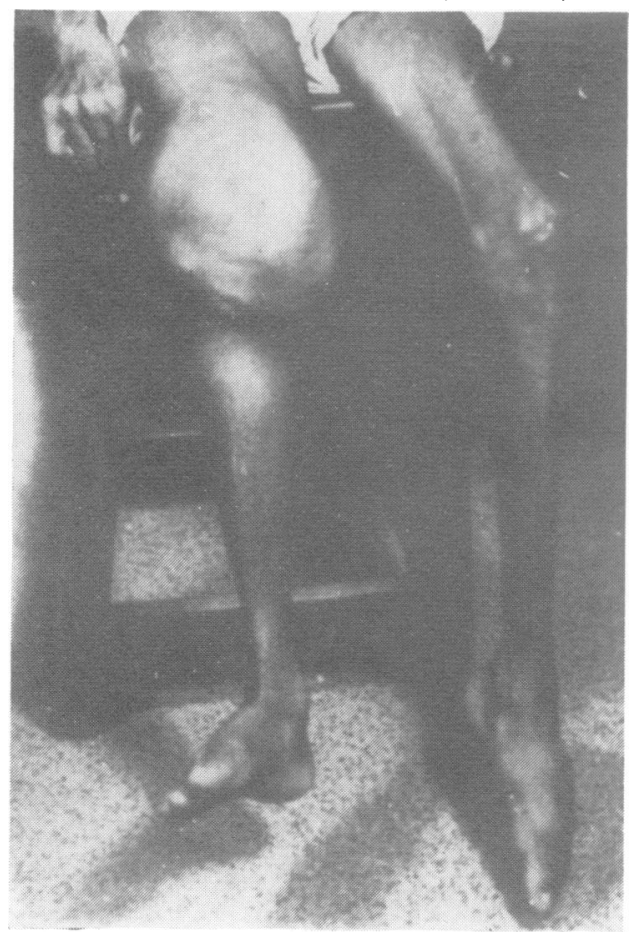

FIG. 1 Multiple Charcot's arthropathy (Case 1) 


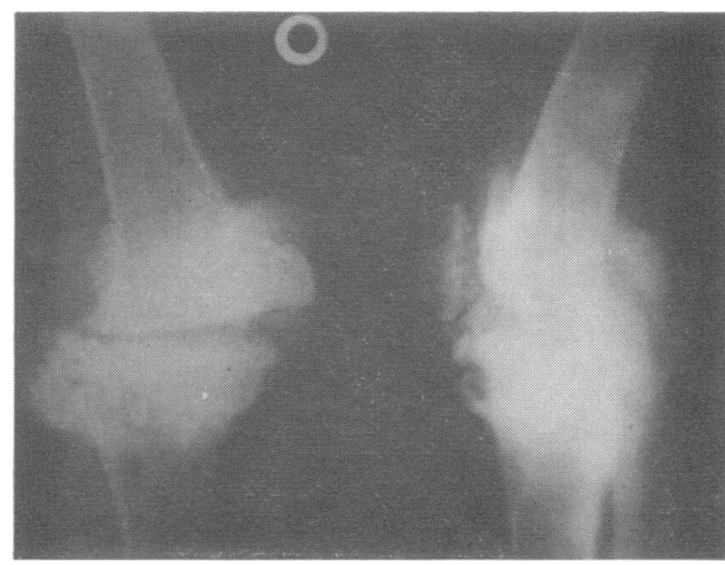

FIG. 2 Skiagrams of right knee (Case 1)

ii Atypical Argyll Robertson (AR) pupils (dilated, but with all the other features of AR pupils)

iii Gastric crises

iv Evidence of posterior column involvement (loss of ankle jerks and knee jerks, loss of vibration sense, and testicular sensation).

The Venereal Diseases Research Laboratory Slide (VDRL) test and Treponemal Immobilization (TPI) test gave positive results on serum and on the cerebrospinal fluid (CSF) which showed no other active changes.

A diagnosis of tabes dorsalis was made; antisyphilitic treatment consisting of 120 m.u. procaine penicillin $G$ in oil with 2 per cent. aluminium monostearate (PAM) was given over a period of 3 years (1963-1965). In addition, prednisolone $10 \mathrm{mg}$. three times a day for 10 days, tapering off over 8 days (total $370 \mathrm{mg}$.) and fever therapy were given. To control the gastric crises, stemetil (prochlorperazine) and largactil (chlorpromazine) were given whenever necessary.

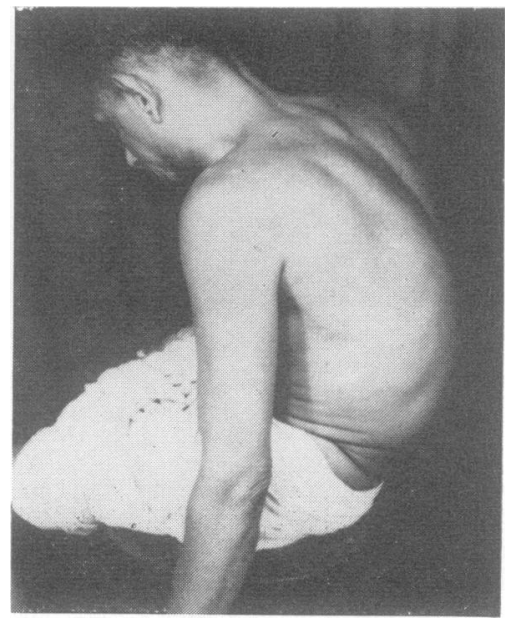

Fig. 3 Charcot's arthropathy of spine (Case 1)

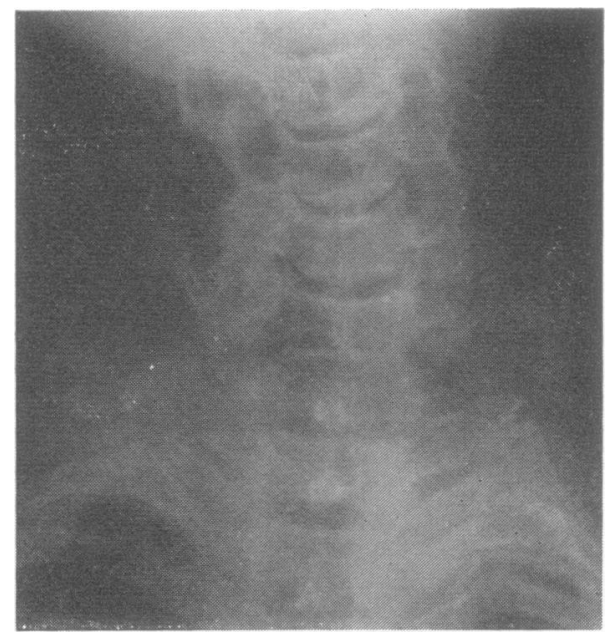

Fig. 4 Skiagram of 6 th and 7 th cervical vertebrae (Case 1)

PROGRESS

The subsequent progression of the clinical manifestations and the treatment given were as follows:

1965-Gastric crises had almost disappeared; occasionalo vertigo.

1966-Extreme malnutrition; Charcot's arthropathy of the 6th and 7th cervical and 3rd, 4th, and 5th lum-? bar vertebrae (Figs 3 and 4, and Fig. 5, overleaf). The patient was treated for malnutrition and a further 24 m.u. PAM were given.

1968-Injury of left wrist followed by development of Charcot's arthropathy (Figs 6 and 7, overleaf).

1969-Lightning pains developed mainly in the amputated right leg and in the left thigh.

1970-Intractable attacks of urticarial rash for which no specific reason could be assigned.

LABORATORY DATA CASE 1

\begin{tabular}{|c|c|c|}
\hline Year & $\begin{array}{l}\text { Serological tests for } \\
\text { syphilis }\end{array}$ & $C S F$ \\
\hline $\begin{array}{l}1962 \text { (before } \\
\text { treatment) }\end{array}$ & $\begin{array}{l}\text { VDRL-reactive (dilution } \\
1 \text { in } 4 \text { ) } \\
\text { TPI-reactive }\end{array}$ & $\begin{array}{l}5 \text { cells } / \mathrm{cu} . \mathrm{mm} \text {. } \\
40 \mathrm{mg} \text {. per cent. } \\
\text { protein } \\
\text { VDRL reactive in } 1 \\
\text { dilution }\end{array}$ \\
\hline $\begin{array}{l}1963 \text { (6 months } \\
\text { after treatment) }\end{array}$ & As before & $\begin{array}{l}2 \text { cells } / \mathrm{cu} . \mathrm{mm} . \\
38 \mathrm{mg} \text {. per cent. } \\
\text { protein } \\
\text { VDRL nonreactive }\end{array}$ \\
\hline $1965-1970$ & $\begin{array}{l}\text { VDRL-nonreactive } \\
\text { FTA-ABS-reactive }\end{array}$ & $\begin{array}{l}2 \text { cells/cm. mm. } \\
23 \mathrm{mg} \cdot \text { per cent. } \\
\text { protein } \\
\text { VDRL nonreactive } \\
\text { FTA test-reactive }\end{array}$ \\
\hline
\end{tabular}

Examination of lymph-node tissue, tissue from the Charcot's joint and of the CSF did not show any spiralshaped organisms, either by darkfield (DF) microscopy, by fluorescent antibody (FA) technique, or by the intratesticular inoculation of rabbits. 

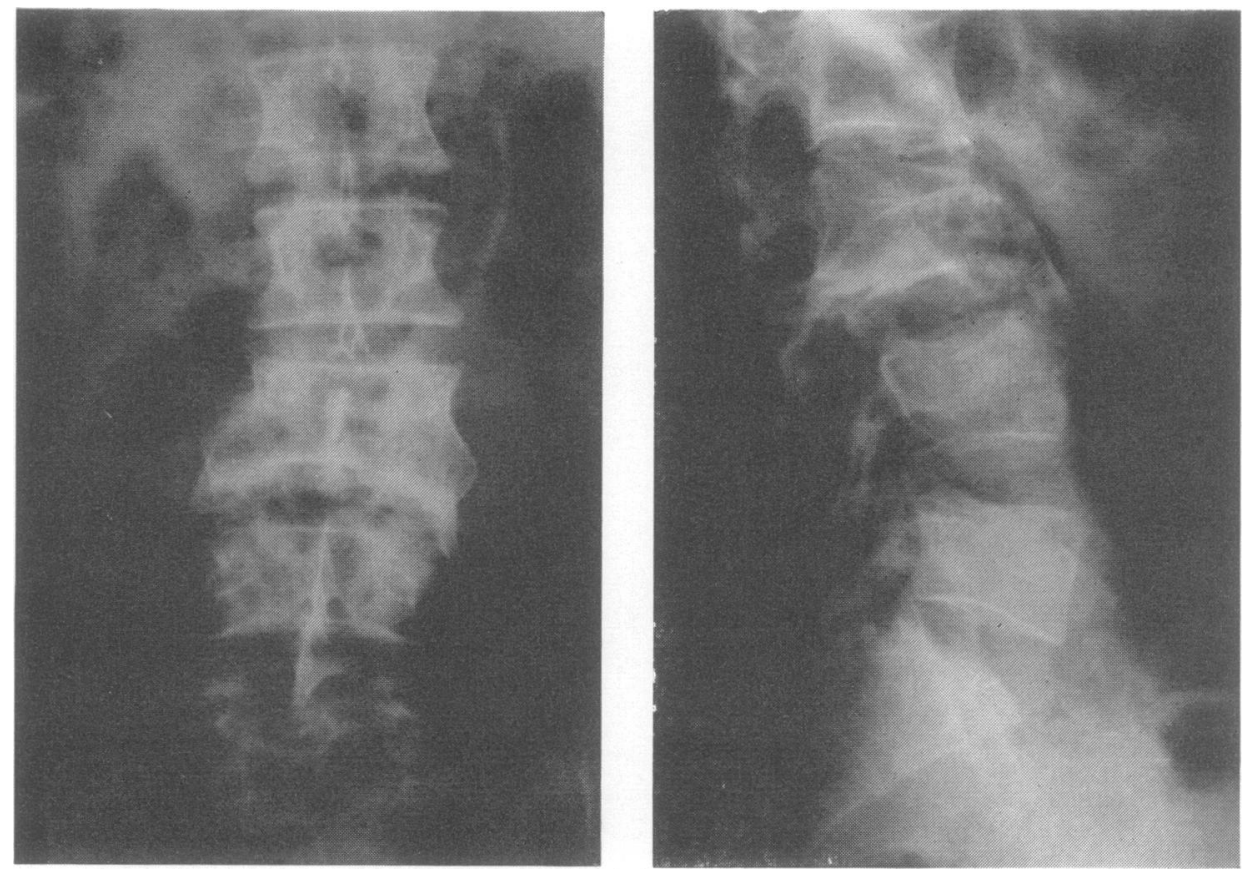

FIG. 5 Antero-posterior and lateral views of $3 r d$ and 4 th lumbar vertebrae (Case 1)

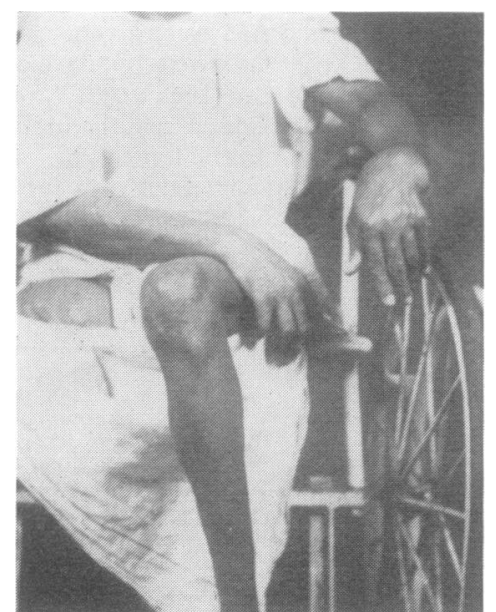

FIG. 6 Charcot's arthropathy of left wrist (Case 1)

\section{COMMENT}

The case of this patient, who was observed for more than 8 years, illustrates the steady progression of late neurosyphilis, despite repeated and prolonged treatment with penicillin. However, some symptoms, e.g. the gastric crises, abated. The pupils remained the same. Tre-

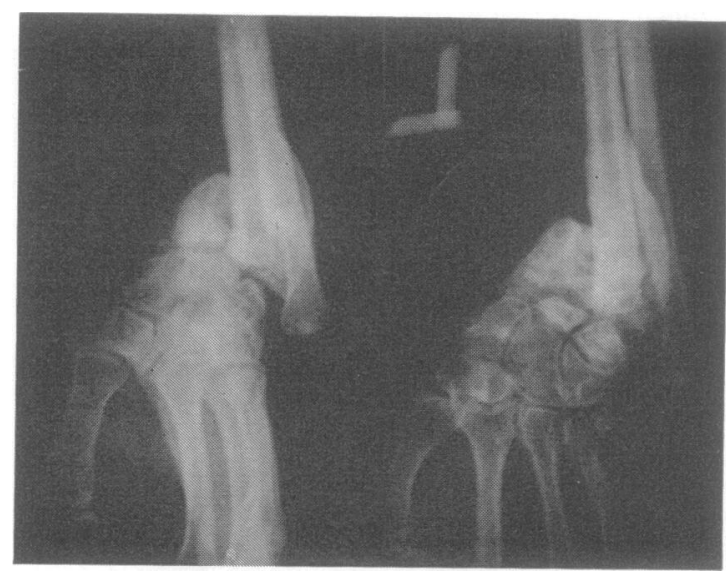

FIG. 7 Skiagrams of left wrist (Case 1)

ponemes were not seen in the affected tissues and lymphnodes. The serum FTA-ABS and CSF FTA test were reactive and afforded the only persisting laboratory evidence to indicate the presence of syphilitic infection. The effects of malnutrition and injury may have contributed to the progression of the syphilitic lesions. 
Case 2, a 37-year-old man, was first seen in 1957 with retinitis proliferans, hemiplegia on the right side, and 3rd, 4th, and 6th cranial nerve paralyses on the left side of 6 months' duration (Fig. 8). He was a highly promiscuous individual who had had repeated attacks of genital ulceration; he had had a few injections of penicillin at different times.

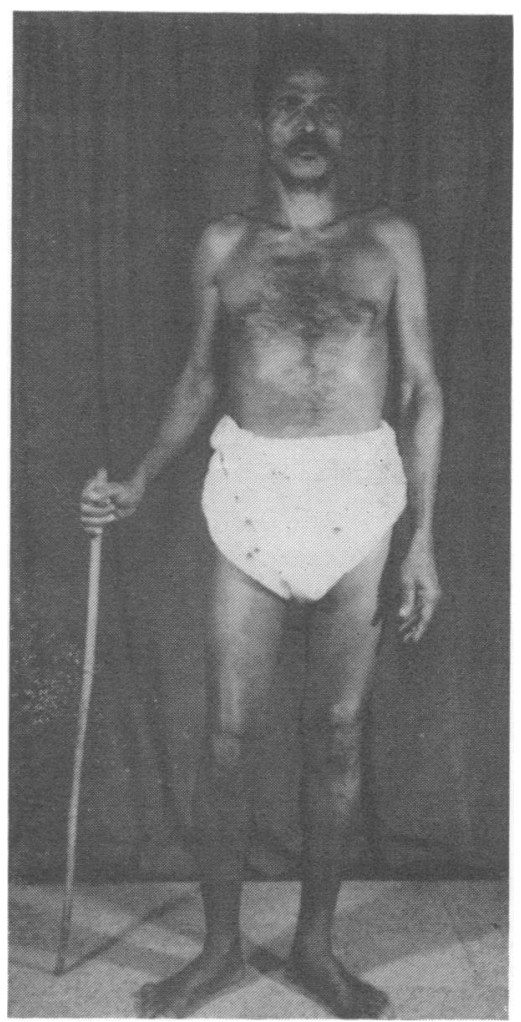

Fig. 8 Right hemiplegia and left $3 r d, 4 t h$, and 6 th cranial nerve paresis (Case 2)

The VDRL test was reactive (dilution 1 in 4 ) on serum and in CSF (dilution 1 in 4) which otherwise showed no active changes.

He was given two courses each of 600,000 units PAM daily for 20 days ( $12 \mathrm{~m} . \mathrm{u}$.). In spite of his disability, he remained highly promiscuous but developed no genital lesions. He attended the Institute once or twice a year, and each time he received a further course of $12 \mathrm{~m}$.u. PAM.

The CSF and tissue from the left little toe and from the lacrimal sac were examined for treponemes by darkfield microscopy and by the FA technique with negative results.

\section{COMMENT}

This was a case of inadequately treated early syphilis in a promiscuous individual with involvement of the eyes and the central nervous system. The physical signs later progressed unchecked despite repeated 'adequate treatment'.

\section{LABORATORY DATA CASE 2}

\begin{tabular}{|c|c|c|}
\hline Year & Clinical findings & Laboratory findings \\
\hline $\begin{array}{l}1959,1960 \\
1963\end{array}$ & $\begin{array}{l}\text { Unchanged. No genital } \\
\text { ulcers }\end{array}$ & $\begin{array}{l}\text { Serum VDRL-positive } \\
(1: 4) \\
\text { CSF No cells } \\
42 \mathrm{mg} \text {. per cent. protein } \\
\text { VDRL reactive in } 1 \\
\text { dilution }\end{array}$ \\
\hline 1964 & $\begin{array}{l}\text { In addition, he had binasal } \\
\text { hemianopia }\end{array}$ & As in 1963 \\
\hline 1965,1967 & As in 1961 & $\begin{array}{l}\text { Serum VDRL-reactive } \\
\text { (undiluted) } \\
\mathrm{CSF} \text {-normal }\end{array}$ \\
\hline 1968 & $\begin{array}{l}\text { Chronic ulcer at base of } \\
\text { right little toe and between } \\
\text { this and fourth toe (Fig. 9) }\end{array}$ & As in 1967 \\
\hline 1969 & $\begin{array}{l}\text { Charcot's arthropathy of } \\
\text { right little toe (Fig. 10) }\end{array}$ & $\begin{array}{l}\text { Serum VDRL-reactive } \\
\text { CSF FTA-reactive }\end{array}$ \\
\hline 1970 & $\begin{array}{l}\text { Chronic dacryocystitis left } \\
\text { side (Fig. 11) }\end{array}$ & $\begin{array}{l}\text { Serum FTA-ABS- } \\
\text { reactive } \\
\text { CSF No cells } \\
30 \mathrm{mg} \text {. per cent. protein } \\
\text { VDRL nonreactive } \\
\text { FTA reactive }\end{array}$ \\
\hline
\end{tabular}

Treponemes were not seen in the affected tissue. The serum FTA (ABS) and CSF FTA tests were both reactive

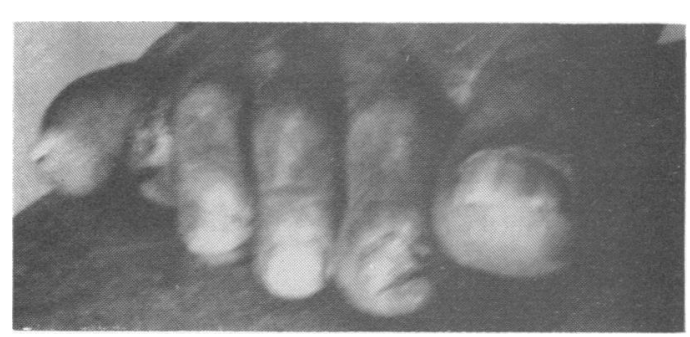

FIG. 9 Charcot's arthropathy of right little toe ano ulceration between this and the 4th toe (Case 2)

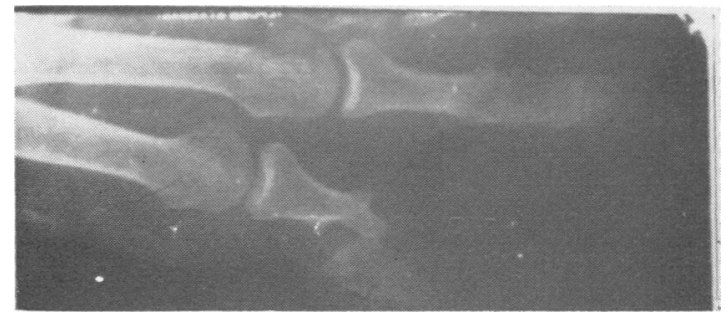

FIG. 10 Skiagram of right little toe (Case 2)

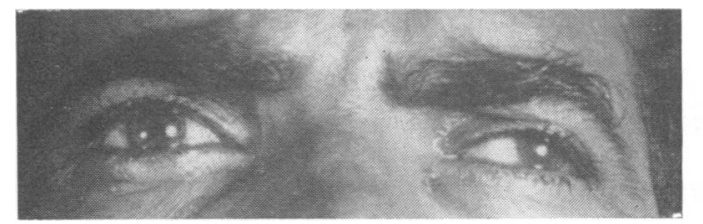

FIG. 11 Chronic dacryocystitis on left side (Case 2) 
Case 3, a 33-year-old man, was seen in 1959 at the Institute of Venereology because of a flat complete detachment of the retina on the left side. The right eye was normal with full vision.

Syphilis had been diagnosed 10 years earlier and he had received antisyphilitic treatment with arsenic and bismuth, and later with sixty injections of penicillin (dosage not known).

The serum VDRL test was reactive. The CSF was normal. He was given 24 m.u. PAM.

He returned in 1963, and stated that he had had pulmonary tuberculosis in 1961 and had had a full course of antituberculous therapy for 6 months. In 1963 he could only perceive light with his left eye which showed macular degeneration, pigmentary disturbance, and vitreous opacities. In the right eye there were vitreous opacities reducing the vision to $3 / 60$. He received another four courses of PAM, each course consisting of 600,000 units daily by intramuscular injection for 20 days.

In 1969 the right eye became blind. The left eye was unchanged but in the right eye there was evidence of progression, the pupil being irregular and fixed, with congestion and increased ocular tension. In addition, the patient had developed Rombergism, loss of ankle and knee jerks, incontinence of urine, and widening of the aorta on radiography. The lung fields were clear. The CSF and aqueous humour were both examined for treponemes but no organisms were found.

\section{COMMENT}

In this case, progression of the disease occurred in the eyes, the central nervous system, and the cardiovascular system in spite of massive doses of penicillin. The only persisting laboratory evidence of syphilitic infection was the reactive serum VDRL and FTA (ABS) tests. The CSF was normal.

Case 4, a 12-year-old girl was seen in 1951 suffering from acute bilateral interstitial keratitis. She had Hutchinsonian upper central incisors, shortening of the left middle finger due to old dactylitis and multiple 'tissue-paper' scars over the face and both lower extremities.
The blood Wassermann reaction and Kahn test were positive. She was treated with 600,000 units PAM by intramuscular injection daily for 10 days. fever therapy with killed typhoid bacilli, and 1 per cent. hydrocortisone eye ointment.

\section{SUBSEQUENT HISTORY, AND CLINICAL AND LABORATORY FINDINGS (see Table below)}

In 1968, during the cataract operation, specimens of aqueous humour and lens tissue were obtained for examination for treponemes by darkfield microscopy and also by the FA technique. $0.1 \mathrm{ml}$. aqueous humour was inoculated intratesticularly into a rabbit. In 1968 and 1970 the foetal tissues were examined by darkfield microscopy and serological tests were performed on the foetal blood. All these tests gave negative results.

\section{COMMENT}

In spite of presumably adequate antisyphilitic treatment, this patient developed progressive uveitis, lens changes, and glaucoma (Fig. 12). The serum and CSF after treatment were normal. Treponemes were not demonstrated in the aqueous humour, the lens, and the foetal tissues. The only evidence of syphilitic infection was given by the historical data and the stigmata of congenital syphilis. The progression in this case cannot be attributed to any specific cause.

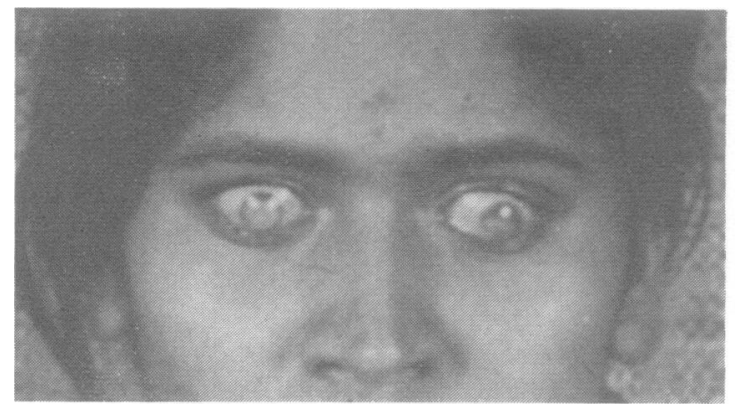

FIG. 12 Total blindness in a case of congenital syphilis (Case 4)

LABORATORY DATA CASE 4

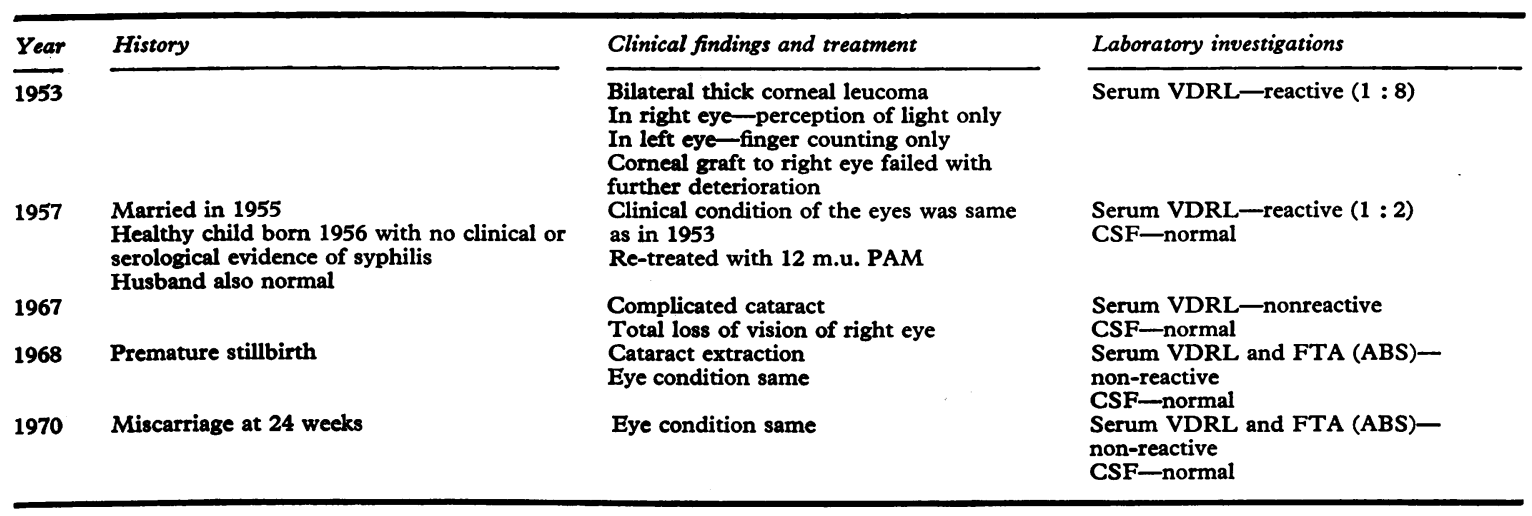


Case 5, a 45-year-old man, was first seen at the Institute of Venereology in 1957, with a history of repeated attacks of fits and with the following psychiatric, neurological, and ocular manifestations. $\mathrm{He}$ was an emotionally disturbed person with normal intelligence, memory, and speech. There were tremors of the tongue and of the outstretched hands, convergent squint, and horizontal nystagmus on the left side. The hand-writing was illegible. There was loss of knee and ankle jerks, vibration sense, and deep pressure sensation over the calf muscles and Achilles tendon. There were patches of choroido-retinitis in both eyes with thinning of the retinae and a waxy appearance of the optic discs. The visual acuity was reduced to $3 / 60$ in the right eye and $1 / 60$ in the left. The visual fields were concentrically contracted.

This patient had had a genital sore in 1941 and a skin rash in 1943. His wife had latent syphilis and their second child had Hutchinsonian central upper incisors, but the VDRL and TPI were both nonreactive.

The serum VDRL was reactive in 16 dilutions. The CSF showed 10 cells per cu. mm., $72 \mathrm{mg}$. per cent. protein, VDRL reactive in 4 dilutions, and Lange colloidal gold 5554433100 .

A diagnosis of taboparesis with choroido-retinitis in both eyes and commencing optic atrophy was made.

Antisyphilitic treatment, consisting of repeated courses of PAM (total 36 m.u.) and fever therapy, was given. By 6 months after the start of treatment the fits had stopped. The CSF showed 1 cell per cu. mm., $44 \mathrm{mg}$. per cent. protein, VDRL nonreactive, FTA reactive, colloidal gold 4431000000 .

The squint, nystagmus, tremors of the tongue and of the outstretched hands, and the posterior column involvement were still present. The hand-writing became legible after the treatment. However, over a period of 10 years, the visual disturbance became more pronounced, so that the visual acuity dropped to $1 / 60$ in the right eye and the left eye became totally blind. Both optic discs became markedly atrophic. The field of vision even of the right eye could not be charted. Examination of the aqueous humour and CSF failed to reveal treponemes.

\section{COMMENT}

In this case of taboparesis, choroido-retinitis, and commencing optic atrophy, the ocular condition progressed despite adequate antisyphilitic treatment; but the fits disappeared. The FTA test remained reactive in the CSF.

Case 6, a 50-year-old man, presented himself at the Institute of Venereology in 1964 because of bilateral painless swelling of both kness (Fig. 13). The clinical condition was diagnosed as syphilitic Charcot's arthropathy on historical, epidemiological, serological, clinical, and radiological grounds. He was treated with 600,000 units PAM by daily intramuscular injections for 20 days. He received a total of five such courses between 1964 and 1967. In 1969 he came back, unable to walk and with evidence of malnutrition. There was now gross deformity of both knee joints (Fig. 14). He was again treated with 24 m.u. PAM. In 1970 he returned with loss of vision in the right eye, incontinence of urine, and Rombergism, and the

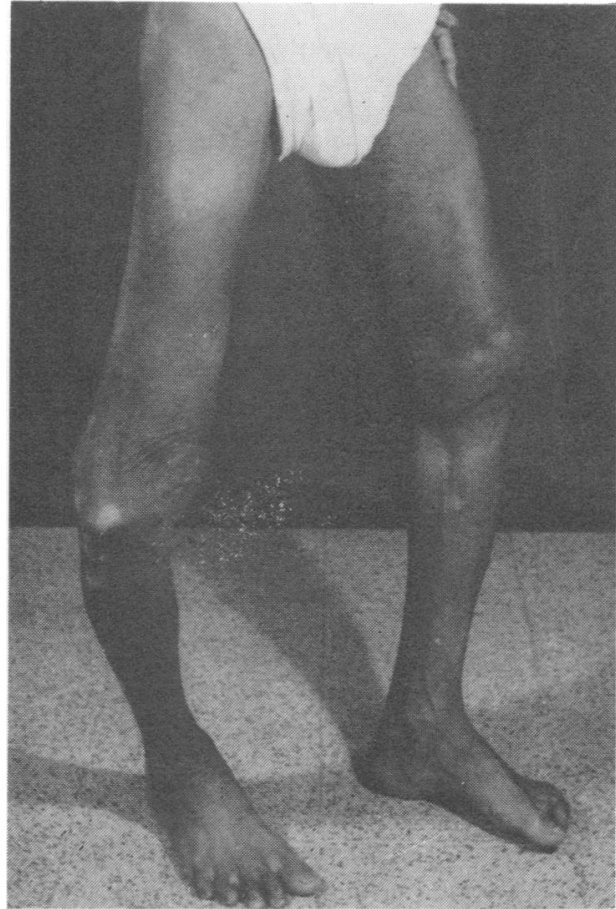

FIG. 13 Charcot's arthropathy of the knees (Case 6)

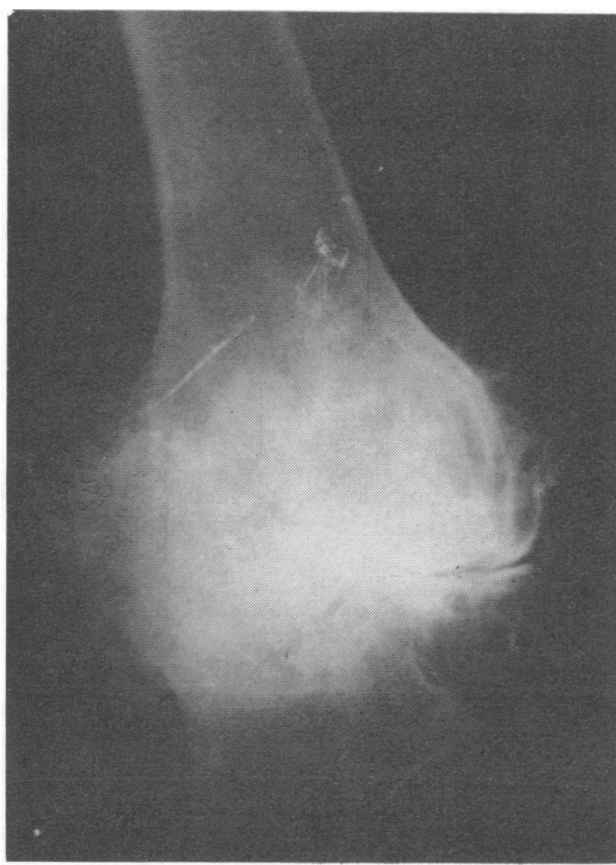

FIG. 14 Skiagram of left knee (Case 6) 
knee joints were so unstable that even standing erect was difficult. A detailed examination of the eyes revealed deep keratitis and iritis in the right eye (Fig. 15) and marked choroidal sclerosis on both sides, more on the right side. The vision in the right eye was reduced to perception of light and that of the left eye to $3 / 60$. There was also evidence of posterior column involvement (Rombergism, incontinence of urine, and loss of knee and ankle jerks and deep-pressure sensation).

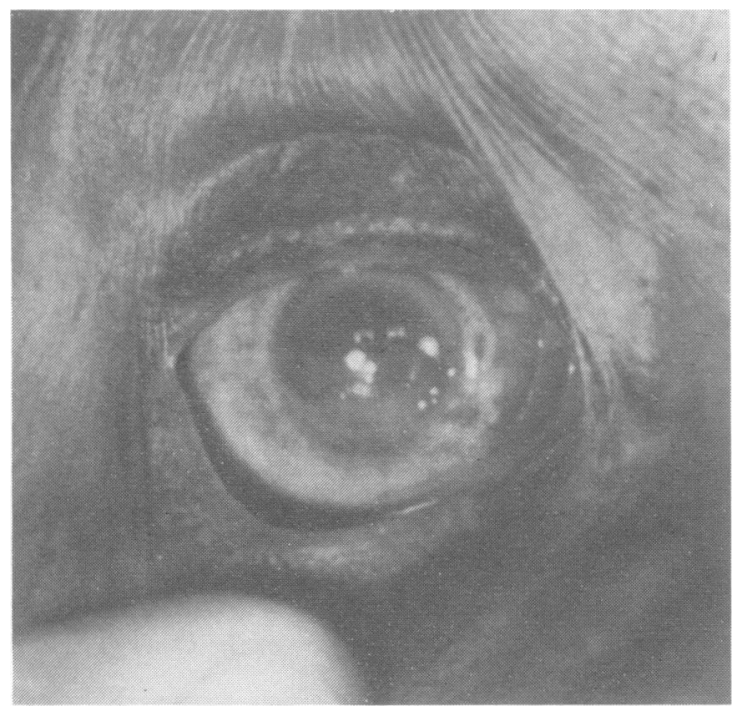

FIg. 15 Keratitis and iritis of right eye (Case 6)

The serum VDRL, which had originally been reactive at a dilution of $1:$ in 128 in 1964, was reactive at a dilution of $1: 8$ in 1970. The FTA (ABS) test was also reactive. The CSF at no time showed any evidence of activity or reactivity to tests for reagin and antitreponemal antibodies.

\section{COMMENT}

This patient developed eye changes and marked posterior column involvement. Nutritional factors may have played a part in this progression. No treponemes could be found in the synovium, aqueous humour, or CSF.

Case 7, a 56-year-old man, was first seen in 1957 at the Institute of Venereology with bilateral Argyll Robertson pupils, disseminated choroiditis, and minimal posterior column involvement.

He had historical, clinical, and serological evidence of past and present syphilitic infection. The CSF showed the changes of neurosyphilis: 12 cells per cu. $\mathrm{mm} ., 50 \mathrm{mg}$. per cent. protein, VDRL reactive in 8 dilutions.

In 10 years, despite repeated courses of antisyphilitic treatment, he developed the additional features of occasional nocturnal incontinence, Charcot's arthropathy of both knees (Fig. 16), bilateral cataract, and further deterioration of vision resulting in the disappearance of the AR pupil reaction. In 1964 he had bilateral pulmonary tuberculosis, for which antituberculous therapy was given.
The serum VDRL which was originally reactive at a dilution of 1 in 16 in 1957 was reactive at a dilution of 1 in 2 in 1967. The CSF showed 2 cells per cu. $\mathrm{mm}$., $48 \mathrm{mg}$. per cent. protein, VDRL nonreactive.

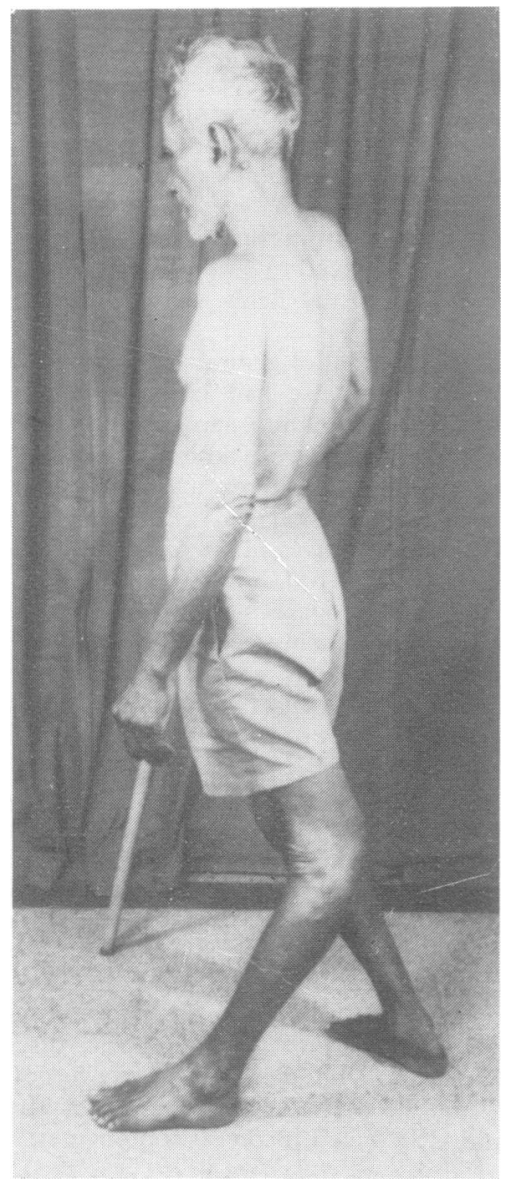

FIG. 16 Charcot's arthropathy of knees (worse on the left) (Case 7)

\section{COMMENT}

In spite of antisyphilitic treatment, the degenerative process continued. It is possible that the concomitant tuberculous infection affected the course of the disease and the response of the syphilitic infection to therapy. Another interesting feature was the difficulty in appreciating the AR pupil reaction with the further deterioration of vision which was most probably due to degenerative changes in the retina. No treponemes could be found in the CSF or aqueous humour.

\section{Summary and conclusion}

Seven cases of late ocular and neurosyphilis are described. Six of these seven cases, in which disease 
progressed despite anti-syphilitic treatment, had reactive tests for syphilis either in serum or in CSF in addition to historical, epidemiological, and clinical evidence to establish a diagnosis of syphilitic infection. In one case of treated congenital syphilis with interstitial keratitis, the serological tests had become nonreactive. Two patients had concomitant tuberculosis and two had gross malnutrition.

The persistence of Treponema pallidum despite treatment has been demonstrated in late cases (Collart and others, 1962; Yobs and others, 1964). In these seven cases the failure to demonstrate treponemes in body fluids or in tissues showing clinical progression, does not eliminate the possibility that these organisms were present in the lesions. Nevertheless, it is to be expected that some forms of disease may progress because of irreversible tissue damage due to syphilis whether the causative organisms have been eliminated by treatment or not.

Thus the neurological lesions of tabes dorsalis led to the development of fresh Charcot's arthropathy in four cases and of a perforating ulcer in one. It may well be that the signs of neurological damage, including optic atrophy, may increase after treatment because of sclerotic rather than specific changes in the affected tissues. Certainly the damage resulting from syphilitic iritis may lead to glaucoma. It is possible that chronic infections like tuberculosis, leprosy, and filariasis, which are prevalent in tropical areas, may contribute to clinical progression. Two patients had tuberculosis, and two had definite evidence of malnutrition when admitted for treatment.

I am grateful to the Dean of the Government General Hospital, Madras, and to the Government of Tamil Nadu for providing facilities to carry out this study.

\section{References}

Collart, P., Borel, L.-J., and Durel, P. (1962) Ann Inst. Pasteur, 102, 596.
Yobs, A. R., Rockwell, D. H., and Clark, J. W., Jr. (1964) Brit. F. vener. Dis., 40, 248.

Aggravation clinique de la syphilis oculaire et de la neurosyphilis malgré le traitement par des doses massives de pénicilline

\section{SOMMAIRE}

Six des sept cas rapportés, dans lesquels la maladie évolua malgré le traitement anti-syphilitique, avaient eu une sérologie positive pour la syphilis en plus des preuves historiques, épidémiologiques et cliniques établissant le diagnostic de l'infection syphilitique. Dans un cas de syphilis congénitale traitée pour une kératite interstitielle, les épreuves sérologiques étaient devenues négatives. Deux malades avaient une tuberculose simulantée, et deux, des signes d'importante de mal nutrition.

La persistence de Treponema pallidum malgré le traitement a été prouvée dans des cas tardifs (Collart et al., 1962; Yobs et al., 1964). Dans les sept présents cas, l'impossibilitié de mettre en évidence les tréponèmes dans les tissus en progression clinique, n'élimine pas la possibilité que ces organismes n'y soient présents. Néanmoins, on peut penser que certaines formes de la maladie puissent progresser cliniquement du fait d'altération tissulaire irréversible dûe à la syphilis, que les organismes responsables eussent été ou non éliminés par le traitement. Ainsi, les lésions neurologiques du tabes ont entraîné une arthropoathie de Charcot récente dans quatre cas, et un ulcère perforant dans un cas. Il est bien possible que les signes d'altération neurologique-ceci comprenant l'atrophie optique-puissant se developper après traitement du fait de la sclérose plutôt que du fait d'altérations spécifiques des tissus atteints. Certainement, les lésions déterminées par une iritis syphilitique peuvent conduire au glaucome. Il est possible que des infections chroniques telles que la tuberculose, la lèpre, la filariose, qui sont fréquentes dans les zones tropicales, puissent intervenir sur l'aggravation clinique. Lors de leur admission pour traitement, deux malades avient une tuberculose et deux des preuves evidentes de mal nutrition. 